\title{
Assessment of genetic diversity in Cattleya intermedia Lindl. (Orchidaceae)
}

\author{
Nelson Barbosa Machado Neto ${ }^{1 *}$ and Luiz Gonzaga Esteves Vieira ${ }^{1,2}$ \\ ${ }^{1}$ Universidade do Oeste Paulista; Rod. Raposo Tavares, km 572; 19067-175; Presidente Prudente - SP - Brasil. \\ ${ }^{1,2}$ IAPAR; Rod. Celso Garcia Cid, km 375; C. P.: 481; 86047-902; Londrina - PR - Brasil
}

\begin{abstract}
Orchids are valuable pot plants and Cattleya intermedia is a promising species underused in breeding programs. Recently, breeding work with this species produced superior plants that are believed to be not the true species owing to the morphological differences from wild plants. The aim of this study was to estimate the level of genetic diversity and interrelationships between wild and bred Cattleya intermedia collected at three different Brazilian states and from commercial breeders with RAPD markers. A total of 65 polymorphic bands were used to generate a genetic distance matrix. No specific groupings were revealed by the cluster analysis as bred materials were not different from wild plants. The genetic differentiation $\left(F_{S T}=0.01626\right)$ was very low indicating a high gene flow in $\mathrm{C}$. intermedia due to artificial crosses and a high differentiation between populations. The genetic variability available within this species is high enough to allow genetic progress in flower shape and size.
\end{abstract}

Key words: $\mathrm{F}_{\mathrm{st}}$, domestication, molecular markers, genetic variability, orchids

\section{INTRODUCTION}

Orchidaceae is the largest botanical family ranging from 7 to 10 percent of the flowering plant species (Dressler, 1993; 2005). Orchid commercialization, both pot plants and cut flowers, is highly significant worldwide and is increasing year after year. Cattleya, together with Cymbidium, Phalaenopsis and Dendrobium, are important commercial ornamental species due to its large spectrum of colors and relatively high cross ability with other genera. Cattleya species are among the most important plant genera for pot and flower orchid trade industry. The number of described species in this genera is still a matter of debate, ranging from 49 (including Cattleyella and Guarianthe, Withner, 1988) to 112 species (excluding Guarianthe and Cattleyella and including Sophronitis sensu van den Berg, van den Berg, 2008).

Cattleya intermedia is native from the South Atlantic rainforest, a biodiversity hotspot highly endangered by human activities. It is distributed from Uruguay, in the south, to the Brazilian State of Rio de Janeiro, in the north. Classified as a bifoliate Cattleya (Fowlie, 1977), it has a considerable variation in flower colour and shape. The flower of the type specimen is pale rose with the central lobe of the labellum outstandingly detached and darker than the other floral segments. However, $C$. intermedia is one of the most variable orchid species with several desirable characteristics for plant breeding as colour (type, orlate, punctuate, alba, red blood, cerulean, winecoloured and amethystine), shape (normal, peloric and aquini), multi flower stem (5-10 flowers in the

\footnotetext{
*Author for correspondence: nbmneto@unoeste.br
} 
wild forms and 3-4 flowers in the bred lines) and medium size flowers $(8-12 \mathrm{~cm})$. Also, it is considered one of the most precocious species within the Cattleya genus, flowering for the first time within three years (Fowlie, 1977; Bicalho, 1977; Withner, 1988; Lacerda et al., 1995). These characteristics have prompted breeding efforts to select superior plants.

Orchid breeding by hybridization is relatively common and easily done, allowing the combination of several genera and the generation of interspecific, intrageneric and intergeneric hybrids. C. intermedia is often used to produce hybrids and their registered offspring surpass 2800 types. Cattleya loddigesii, another fast growing species, but presenting fewer phenotypic variations, is represented by more than 4000 hybrids (Wildcatt, 2002). On the other hand, species improvement by breeding (intraspecific crosses) is restricted when compared with hybrid breeding (interspecific and intergeneric crossing). This is due to the genetic gain observed in flower shape, substance and texture, that is usually higher at the beginning and tend to lower values in further generations (Allard, 1999).

Species breeding efforts in orchids are questioned because the improved offspring are sometimes very different from the wild types. It is well known that domestication strongly reduces sequence diversity at genes controlling traits of interest (Allard, 1988; Wang et al., 1999; Salamini et al., 2002). In populations submitted to constant selection, where just the superior individuals were promoted for reproduction, the alleles controlling characters of interest had their frequency increased, leading to diversity loss in crop plants (Salamini et al., 2002). In orchids, flower shape, as well as colours, has been improved by breeding; flower number, conversely, has decreased. While in wild specimens of $C$. intermedia it is common to find plants carrying 5 to 6 , or even 10 , flowers per stem, in bred $C$. intermedia cultivars no more than 5 flowers are present even in exceptionally well developed plants.

Two hypotheses have been suggested to explain the highest phenotypic differences observed in $C$. intermedia specimens: 1 . use of improved parents with flower characters that dramatically differ from the wild specimens in breeding strategies, as the peloric or the called "aquinii" forms and 2 . gene introgression from Cattleya loddigesii, which may alter dramatically the flower shape even with backcrossings.

Molecular markers are used in plant breeding programs as they can rapidly assess population variability without environment interference, with advantages over morphological characters, in terms of discrimination, confidence and costs (Assis et al., 2003). PCR (Polymerase Chain Reaction) based protocols allowed an increase in the analysis of the variability or plant systematic (van den Berg et al., 2002; Pires and Sytsma, 2002). Among the various types of molecular markers available, Random Amplified Polymorphic DNA (RAPD) is a methodology that does not require previous genome knowledge, it is cheap and accessible especially when molecular information is scarce (Williams et al., 1990; Weeden, 1992). It has been used to indicate genetic relationships between orchid species (Demeke et al., 1992; Choi et al., 2006), to unravel cultivar identification (Weeden, 1992; Menezes et al. 2002), to study the systematic of Vanda (Lim et al., 1999) and Phalaenopsis (Goh et al., 2006) and to analyse the genetic diversity as in Cymbidium (Choi et al., 2006), Changneienia amoena (Li and $\mathrm{Ge}, 2006)$ and Cypripedium calceolus (Brzosko et al., 2002).

RAPD was an important tool to assess the variability as in Bouganvillea (Srivastava et al., 2009), Catharanthus roseus (Shaw et al., 2009), Coffea (C. arabica autogamous - Diniz et al., 2005; C.canephora allogamous - Ferrão et al., 2009), cassava (Manihot esculenta - Ferreira et al., 2008) and in Aspidosperma (rainforest allogamous tree - Torezan et al., 2005).

In this study, we investigate the variation of wild and bred Cattleya intermedia accessions using Random Amplified Polymorphic DNA (RAPD) to clarify the genetic relationships between bred lines and accessions collected in the wild. To our knowledge, this is the first report of the use of a DNA-based polymorphism assay to assess the level of variability in $C$. intermedia accessions.

\section{MATERIAL AND METHODS}

Plants (accessions) were obtained from Cattleya Germplasm Bank, located at Escola Superior de Agricultura Luiz de Queiroz (ESALQ-USP) (São Paulo, Brazil) or were kindly supplied by breeders (Table 1). 
Table 1 - List of Cattleya intermedia accessions, collection code, flower shape/color, status, geographical of origin (State) and donor.

\begin{tabular}{|c|c|c|c|c|}
\hline Collection code ${ }^{*}$ & Shape/Color Form & Status** & Origin $* * *$ & Donor \\
\hline ESA165 & Type & Wild & RS & ESALQ-USP \\
\hline ESA19928 & Type & Wild & SP & ESALQ-USP \\
\hline ESA20083 & Type & Wild & SP & ESALQ-USP \\
\hline ESA20093 & Type & Wild & SP & ESALQ-USP \\
\hline ESA20110 & Type & Wild & SP & ESALQ-USP \\
\hline ESA20162 & Type & Wild & SP & ESALQ-USP \\
\hline ESA2804 & Type & Wild & SP & ESALQ-USP \\
\hline ESA300 & Type & Wild & SP & ESALQ-USP \\
\hline ESA3028 & Type & Wild & RS & ESALQ-USP \\
\hline ESA4072 & Type & Wild & $\mathrm{SC}$ & ESALQ-USP \\
\hline ESA4077 & Type & Wild & SC & ESALQ-USP \\
\hline ESA4079 & Type & Wild & $\mathrm{SC}$ & ESALQ-USP \\
\hline ESA4082 & Type & Wild & $\mathrm{SC}$ & ESALQ-USP \\
\hline ESA4112 & Type & Wild & SC & ESALQ-USP \\
\hline $\mathrm{AO} 1$ & Alba & Wild & UO & Aurora Orchid House \\
\hline $\mathrm{AO2}$ & Aquini coerulea & Bred line & $\mathrm{RS}$ & Aurora Orchid House \\
\hline AO3 & Type & Bred line & RS & Aurora Orchid House \\
\hline AO4 & Coerulea & Bred line & $\mathrm{RS}$ & Aurora Orchid House \\
\hline AO5 & Multiform & Bred line & $\mathrm{RS}$ & Aurora Orchid House \\
\hline AO6 & Orlata & Bred line & $\mathrm{RS}$ & Aurora Orchid House \\
\hline$A B 1$ & Alba peloric & Bred line & RS & Alceu Berger \\
\hline$A B 2$ & Amethyst & Bred line & RS & Alceu Berger \\
\hline$A B 3$ & Aquini & Bred line & $\mathrm{RS}$ & Alceu Berger \\
\hline AB4 & Sanguinea & Wild & $\mathrm{RS}$ & Alceu Berger \\
\hline AB5 & Flamed hatinger & Bred line & RS & Alceu Berger \\
\hline$A B 6$ & Flamed marginata & Bred line & RS & Alceu Berger \\
\hline$A B 7$ & Bordeaux & Bred line & $\mathrm{RS}$ & Alceu Berger \\
\hline$A B 8$ & Coerulea & Bred line & $\mathrm{RS}$ & Alceu Berger \\
\hline$A B 9$ & Orlata-b46 & Bred line & RS & Alceu Berger \\
\hline OM1 & Type & Bred line & UO & Cotovia Orchid House \\
\hline$O M 2$ & Type & Bred line & UO & Cotovia Orchid House \\
\hline OM3 & Type & Bred line & UO & Cotovia Orchid House \\
\hline OM4 & Type & Bred line & UO & Cotovia Orchid House \\
\hline KS1 & Pintada do Tenente & Wild & $\mathrm{RS}$ & KS Orchid House \\
\hline $\mathrm{SC} 1$ & Type & Wild & SC & Ricardo Scarante \\
\hline $\mathrm{SC} 2$ & Type & Wild & SC & Ricardo Scarante \\
\hline $\mathrm{SC} 3$ & Type & Wild & $\mathrm{SC}$ & Ricardo Scarante \\
\hline $\mathrm{SC} 4$ & Type & Wild & $\mathrm{SC}$ & Ricardo Scarante \\
\hline SC5 & Type & Wild & $\mathrm{SC}$ & Ricardo Scarante \\
\hline SC6 & Type & Wild & $\mathrm{SC}$ & Ricardo Scarante \\
\hline SC7 & Type & Wild & $\mathrm{SC}$ & Ricardo Scarante \\
\hline SC8 & Type & Wild & $\mathrm{SC}$ & Ricardo Scarante \\
\hline SC9 & Type & Wild & $\mathrm{SC}$ & Ricardo Scarante \\
\hline SC10 & Type & Wild & SC & Ricardo Scarante \\
\hline SC11 & Type & Wild & $\mathrm{SC}$ & Ricardo Scarante \\
\hline SC12 & Type & Wild & $\mathrm{SC}$ & Ricardo Scarante \\
\hline SC13 & Type & Wild & SC & Ricardo Scarante \\
\hline GW1 & Type & Wild & $\mathrm{RS}$ & Gerson Willrich \\
\hline GW2 & Coerulea & Wild & $\mathrm{RS}$ & Gerson Willrich \\
\hline$G W 3$ & Type & Bred line & $\mathrm{RS}$ & Gerson Willrich \\
\hline $\mathrm{OG}$ & Type & Wild & $\mathrm{RS}$ & Otto Georg \\
\hline $\mathrm{OG}$ & Suave & Wild & $\mathrm{RS}$ & Otto Georg \\
\hline LJL1 & Venosa & Wild & $\mathrm{RS}$ & Luis J Linnen \\
\hline LJL2 & Flamed amethyst & Bred line & RS & Luis J Linnen \\
\hline $\mathrm{EF}$ & Amethyst & Wild & RS & Eloir Fleck \\
\hline $\mathrm{BM}$ & Type & Wild & RS & Belmiro Muller \\
\hline WRS1 & Aquini I & Wild & RS & Wilson R. Silva \\
\hline WRS2 & Concolor & Wild & RS & Wilson R. Silva \\
\hline
\end{tabular}


Total DNA was extracted from petal fragments preserved in silica gel at $-18^{\circ} \mathrm{C}$ or from young green leaves as described by Doyle and Doyle (1987). The DNA was dissolved in TE buffer $\mathrm{pH}$ 8.0 and quantified at $260 / 280 \mathrm{~nm}$ wavelength in a GENESYS 5 Spectrophotometer (Spectronic Instruments).

PCR was carried out in a reaction volume of $25 \mu 1$ containing Tris buffer (20mM Tris- $\mathrm{HCl}, \mathrm{pH} 8.4)$, $50 \mathrm{mM} \mathrm{KCl}, 1.5 \mathrm{mM} \mathrm{MgCl}, 0.4 \mu \mathrm{M}$ of primer, $0.2 \mu \mathrm{M}$ of each dNTP, $1 \mathrm{U}$ Taq polymerase and 50$75 \mathrm{ng}$ of template DNA. RAPD amplifications were performed in a thermo cycler under the following conditions: $94^{\circ} \mathrm{C}$ for $3 \mathrm{~min}$ for initial denaturation and then 40 cycles of $1 \mathrm{~min}$ at $94^{\circ} \mathrm{C}$, $1 \mathrm{~min}$ at $37^{\circ} \mathrm{C}$ for primer annealing and $90 \mathrm{~s}$ at $72^{\circ} \mathrm{C}$ for chain elongation. An extra step of $5 \mathrm{~min}$ at $72^{\circ} \mathrm{C}$ for final elongation was included. Amplification products were separated by electrophoresis in $1.2 \%$ agarose gel. Gels were stained with ethidium bromide and visualized using Electrophoresis Documentation and Analysis System 120 (Kodak Digital Science, Rochester, NY, USA). A 100bp ladder was used as molecular markers. One hundred and twenty Operon primers (A, C, D, X, Y, Z) were evaluated and only primers with clear and distinct bands present in two different conditions (75ng and 50ng of DNA) were considered for the analysis. Only clear RAPD bands that were reproducible were scored numerically as present (1) or absent (0). Smeared and weak bands were excluded. The binary data obtained was then analysed using the NTSYS PC (Rohlf, 1998). Similarities between all accessions were estimated using Jaccard's Similarity Coefficient. Cluster analyses was conducted on similarity estimates using the unweighted pair-group method, arithmetic average (UPGMA) and the resulting cluster displayed as a dendogram. Bootstrap analysis was done using 1000 replications.

Analysis of Molecular Variance (AMOVA) was calculated by total decomposition of its components among and between accessions using the square distances (Excoffier et al., 1992) using Arlequin program v. 3.11 (Excoffier et al., 2006). Wright's measure of accessions differentiation $\left(\mathrm{F}_{S T}\right)$ was also calculated with Arlequin v. 3.11. $\mathrm{F}_{\mathrm{IS}}$ (inbreeding coefficient) was calculated by the formula: $F_{I S}=1+\left(1-F_{I T}\right) /\left(1-F_{S T}\right) ; \quad$ and $F_{I T}$ (overall fixation index) was calculated by the formula: $F_{I T}=1-(\mathrm{Ho} / \mathrm{He})$ where $\mathrm{Ho}$ is the observed and $\mathrm{He}$ is the expected heterozigosity respectively, obtained by the Arlequin software.

\section{RESULTS AND DISCUSSION}

In Brazil, C. intermedia is distributed in the Atlantic Forest from Rio Grande do Sul $\left(33^{\circ} 31^{\prime}\right.$ $\left.8^{\prime \prime} \mathrm{S}, 53^{\circ} 22^{\prime} 4^{\prime \prime} \mathrm{W}\right)$ to Rio de Janeiro $\left(23^{\circ} 01^{\prime} \mathrm{S}\right.$, $\left.43^{\circ} 32^{\prime} \mathrm{W}\right)$. This ecological amplitude in environment space may be the cause of genetic variability among the $C$. intermedia geographic populations. Due to the fact that the Atlantic forest in Southern Brazil is characterized by a high degree of fragmentation, it is generally agreed that C. intermedia is being subjected to a drastic population decline in humid forests of this region.

The majority of the orchids are alogamous, being pollinated by animals (hummingbirds, bees and butterflies). Allogamous species, by definition, are much more variable than autogamous (Yanaka et al., 2005). In some allogamous species such as Bromus inermis and B. riparius (Ferdinandez and Coulman, 2002) variability among populations is higher than within population. On the other hand, in Lolium multiflorum, these values can reach $98 \%$ within populations (Vieira et al., 2004).

RAPD has been used to study the genetic variability among populations for different number of species, independent of the strategy of reproduction, with success in autogamous (Diniz et al., 2005) or allogamous plants (Ferrão et al., 2009, Shaw et al., 2009, Ferreira et al., 2008). In our study, DNA from individuals representing Brazilian populations (Table 1) was scored for polymorphic RAPD loci. Out of 120 primers used in an initial screen, only seven (A12, A18, C5, C12, C20, D7 and D20) that successfully amplified DNA fragments of all $C$. intermedia accessions were selected and used for statistical analyses. The number of selected fragments amplified by each primer and the percentages of polymorphic bands are shown in Table 2

Selected primers revealed polymorphic bands that varied from $75 \%$ (with OPD-7 and OPD-20) to $100 \%$ (with OPA-12, OPC-12, OPC-20) of polymorphism. Using those primers, a total of 65 bands were generated, with sizes varying from 280 to $2010 \mathrm{bp}$, of which 59 bands (95.8\%) showed polymorphism among the examined individuals. According to Chen et al. (2006) the genetic 
variability and clone diversity of three rare natural populations of Caldesia grandis, could be assessed by means of RAPD study, with just 60 highly reproducible bands. The number of selected fragments amplified by each primer and the percentages of polymorphic bands are shown in Table 2.

Table 2 - Nucleotide sequence, number of bands and number of polymorphic bands of each primer used for RAPDPCR analyses of Cattleya intermedia accesions.

\begin{tabular}{ccccc}
\hline Primers & Sequence $\left(\mathbf{5}^{\prime} \rightarrow \mathbf{3}^{\prime}\right)$ & No. of bands scored & No. of polymorphic bands & polymorphism \% \\
\hline OPA-12 & TCGGCGATAG & 10 & 10 & 100 \\
OPA-18 & AGGTGACCGT & 6 & 5 & 83.3 \\
OPC-05 & GATGACCGCC & 9 & 8 & 88.8 \\
OPC-12 & TGTCATCCCC & 12 & 12 & 100 \\
OPC-20 & ACTTCGCCAC & 12 & 12 & 100 \\
OPD-20 & ACCCGGTCAC & 8 & 6 & 75 \\
OPD-7 & TTGGCACGGG & 8 & 6 & 75 \\
Total & & 65 & 59 & - \\
Mean & & 9.3 & 8.4 & 90.3 \\
\hline
\end{tabular}

The dendrogram resulting from the UPGMA cluster analysis $C$. intermedia using accessions collected at distant places showed that there were no grouping pattern differentiating bred plants and wild accessions (Figure 1). However, since this species is distributed in a large area with complex environments and our data have shown that there is an obvious inter- and intra-populations genetic diversity in $C$. intermedia, we may consider that the found variability is sufficient to encourage continued breeding within the available gene pool. In accordance with other authors that also found a high genetic flow between orchid populations and commercial plants (Brzosko et al., 2002; Azevedo et al., 2007), an induced gene flow due to breeding could be involved in the genetic diversity among the accessions analyzed in this study.

Overall, the differentiation $\left(\mathrm{F}_{\mathrm{ST}}\right)$ between the wild and bred accessions was no significant $(\mathrm{P}<0.05)$ with an average value of 0.01626 . The values of $\mathrm{F}_{\mathrm{ST}}$ changed between the overall populations to local populations - SC, SP or RS, with higher values observed when accessions collected in São Paulo are considered as an isolated subpopulation (Table 3).

A low gene flow could lead to high $\mathrm{F}_{\mathrm{ST}}$ values indicating that populations became endogamic and, consequently, for allogamous species, more vulnerable to gene erosion (Wright, 1978, Allard, 1999, Wallace, 2002, Holsinger and Wallace, 2004).

According Wright (1978) $\mathrm{F}_{\mathrm{ST}}$ values ranging from 0 to 0.05 indicates that subpopulations are not genetically different. In our case, the $\mathrm{F}_{\mathrm{ST}}$ for all population (0.01626) and their subpopulations (RS 0.02515 , SC 0.02142 and SP 0.03060) shows that the origin -bred lines and accessions collected in the wild, had a great influence on the results, as with the exception of plants of unknown provenance, all bred lines are originated from RS. These findings could be probably the result of the extensive use of SC and RS $C$. intermedia plants in breeding programs, which affect directly the gene flow. Also, the genetic difference of SP plants from both RS and SC accessions, and the low use of the formers in breeding programs, could make them a valuable source of variability for genetic improvement.

In Platanthera leucophaea, a rare and endangered orchid, the $\mathrm{F}_{\mathrm{ST}}$ values from RAPD and allozyme markers ( 0.889 and 0.754 , respectively) were consistent among both kind of markers and indicated a large amount of endogamy as suggested by Walace (2002) and Holsinger and Wallace (2004). This was also the case in Anthirrhinum subbaeticum (Scrophulariaceae), an endemic endangered plant of Spain, in which $\mathrm{F}_{\mathrm{ST}}$ values ranged from 0.64231 to 0.91061 (Jimenez et al., 2002).

However, Cypripedium calceolus (lady's slipper orchid) showed very low $\mathrm{F}_{\mathrm{ST}}(0.014)$, even in a population characterized by extensive vegetative propagation (Brzosko et al., 2002). Ambiel et al. (2008, 2010) estimated that $\mathrm{F}_{\mathrm{ST}}$ values ranged from 0.244 to 0.437 in Brachiaria, with the apomitic species $B$. brizantha showing the lowest $\mathrm{F}_{\mathrm{ST}}$, but with the highest number of polymorphic bands as an indication of higher variability. 


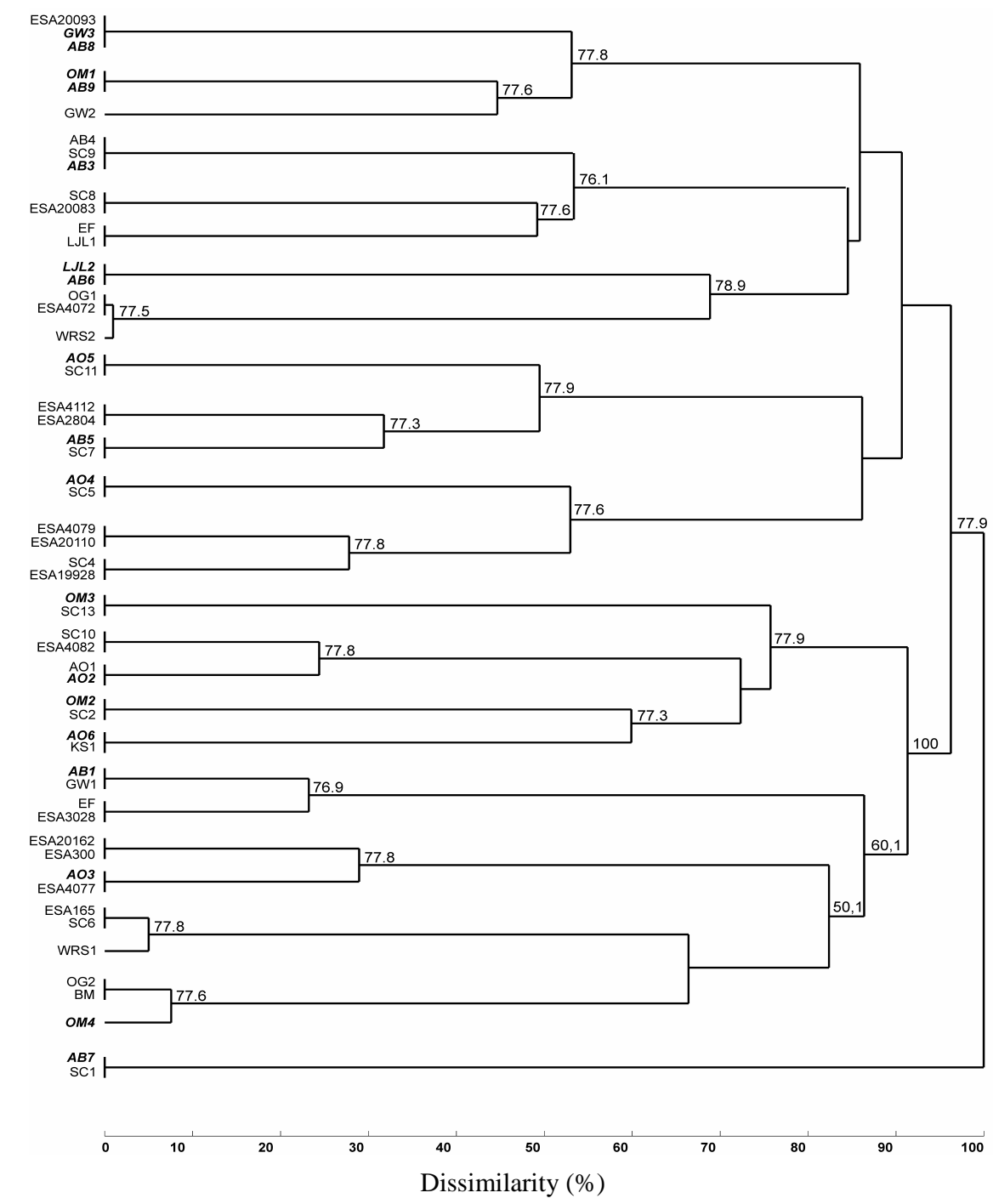

Figure 1 - Dendrogram based on UPGMA cluster analysis and the Jaccard's Similarity Coefficient of RAPD data generated by seven random primers for $58 \mathrm{C}$. intermedia accessions (wild: normal font; bred lines: italic and bold). Numbers on the branches are bootstrap values. Scale (bottom) is the dissimilarity index. The individuals are labelled with the codes listed in Table 1.

Table 3 - Wright's measure of population differentiation $\left(\mathrm{F}_{\mathrm{ST}}\right)$ and inbreeding $\left(\mathrm{F}_{\mathrm{IS}}\right)$, observed $\left(H_{O}\right)$ and estimated Heterosigosity $(\mathrm{He})$ using RAPD markers for Cattleya intermedia and three subpopulations.

\begin{tabular}{lcccc}
\hline Population* & $\mathbf{F}_{\mathbf{S T}}$ & $\mathbf{F}_{\text {IS }}$ & $\boldsymbol{H}_{\boldsymbol{O}}(\boldsymbol{S D})$ & $\boldsymbol{H e}(\mathbf{S D})$ \\
\hline C. intermedia (overall) & $0.01626^{\#}$ & $-0.3201^{\#}$ & $0.5273(0.225)$ & $0.4060(0.113)$ \\
C. intermedia (RS plants) & $0.02515^{\#}$ & $-0.3572^{\#}$ & $0.5372(0.231)$ & $0.4231(0.124)$ \\
C. intermedia (SC plants) & $0.02142^{\#}$ & $-0.3483^{\#}$ & $0.5357(0.242)$ & $0.4018(0.110)$ \\
C. intermedia (SP plants) & $0.03060^{\#}$ & $-0.2930^{\#}$ & $0.5089(0.276)$ & $0.4087(0.119)$ \\
\hline
\end{tabular}

P-value $(<0.05)$

SP - São Paulo State, RS - Rio Grande do Sul State and SC - Santa Catarina State; \# - significant at 5\% by F test.

Cattleya intermedia bred materials are very distinct from wild plants, mainly in characteristics such as flower number and shape, which is consistent with the domestication syndrome as proposed by Koinange et al. (1996) and Wang et al. (1999). In orchids, flower shape, as well as colour, has been improved by Brazilian breeders using superior plants to develop flower quality, but with an additional cost in decreased flower number. If this would happen in the wild it could 
be a trade off event, but in this case is a driven selection effect. In wild specimens of $C$. intermedia, it is frequent to find plants carrying even 10 flowers per stem. On the other hand, even exceptionally developed breeding lines cannot produce more than five good shaped flowers.

Despite these evident morphological differences the analysis of genetic distance using RAPD markers evidenced that the wild and bred $C$. intermedia genotypes are closely related, lacking significant divergences. The decrease genetic variability that is detected in populations due to driven selection (Wang et al., 1999) could be not found in this work. This could be due to the early stages of domestication of $C$. intermedia or by the recurrent use of wild superior forms (selected plants) in the breeding programs. It is also well documented that although most domestication traits are quantitatively controlled, the dramatic morphological changes that accompanied domestication may be due to relatively few genes (Koinange et al., 1996). Therefore, the genetic variability present in the wild and bred $C$. intermedia accessions, including variations in flower shape and number, precocity, texture and substance (the thickness of floral parts), may be the result of plant domestication and the use of superior genotypes.

\section{ACKNOWLEDGMENTS}

We wish to thank all breeders that helped us with plant samples: Alceu Berger (in memoriam), Eloir Fleck, Gerson Willrich, Otto Georg, Anselmo M. Hoff, Belmiro Muller, Luiz J. Linnen, Wilson R. Silva, Carlos Gomes, Ricardo Scarante, Osmar C. Pimentel. To ESALQ-USP Genetic Department that provided some samples of $C$. intermedia.

\section{REFERENCES}

Allard, R.W. (1988), Genetic changes associated with the evolution of adaptedness in cultivated plants and their wild progenitors. $J$ Hered, 79, 225-238

Allard, R.W. (1999), Principles of plant breeding. John Wiley \& Sons New York

Ambiel, A.C.; Guaberto, L.M.; Vanderlei, T.M.; Machado Neto, N.B. (2008), Agrupamento de acessos e cultivares de três espécies de Brachiaria por RAPD. Acta Sci:Agron, 30, 457-464

Ambiel, A.C.; Machado Neto, N.B.; Guaberto, L.M. and Vanderlei, T.M. (2010), Brachiaria germplasm dissimilarity as shown by RAPD Markers. Crop Breed App Biotech, 10, 55-64,

Assis, G.M.L.; Euclydes, R.F.; Cruz, C.D.; Valle, C.B. (2003), Discriminação de espécies de Brachiaria baseada em diferentes grupos de caracteres morfológicos. Rev Bras Zootec, 32, 576-584

Azevedo, M.T.A.; Borba, E.L.; Semir J.; Solferini, V.N. (2007), High genetic variability in Neotropical myophilous orchids. Bot J Linn Soc, 153, 33-40

Bicalho, M. (1977), Native Orchids of Brazil; Associação Orquidofila de São Paulo

Brzosko, E.; Wróblewska, A. and Ratkiewicz, M. (2002), Spatial genetic structure and clonal diversity of island populations of lady's slipper (Cypripedium calceolus) from the Biebrza national park (northeast Poland). Mol Ecol, 11, 2499-2509

Chen. J-M.; Gituru, W.R.; Wang, Y-H. and Wang, Q-F. (2006), The extent of clonality and genetic diversity in the rare Caldesia grandis (Alismataceae): Comparative results for RAPD and ISSR markers. Aquat Bot, 84, 301-307

Choi, S.H.; Kim, M.J.; Lee, J.S. and Ryu, K.H. (2006), Genetic diversity and phylogenetic relationship among and within species of oriental cymbidiums based on RAPD analysis. Sci Hortic, 108, 79-85

Demeke, T.; Adams, R.P. and Chibbar, R. (1992), Potential taxonomic use of Random amplified DNA (RAPD): a case study in Brassica. Theor App Gen, 84, 990-994

Doyle, J.J.and Doyle J.L. (1987), A rapid DNA isolation method for small quantities of fresh tissues. Phytochem Bull Bot Soc Amer, 19, 11-15

Dressler, R.L. (1993), Phylogeny and Classification of the orchid family. Dioscorides Press. Oregon

Dressler, R.L. (2005), How Many Orchids Species. Selbyana 26, 155-158

Diniz, L.E.C.; Ruas, C.F.; Carvalho, N.P.; Torres, F.M.; Ruas, E.A.; Santos, M.O.; Sera, T. and Ruas, P.M. (2005), Genetic diversity among forty coffee varieties assessed by RAPD markers associated with restriction digestion. Braz Arch Biol Tech 48, 511-521

Excoffier, L.; Smouse, P.E. and Quattro, J.M. (1992) Analysis of molecular variance inferred from metric distances among DNA haplotypes: Application to human mitochondrial DNA restriction data. Genet, 131,479-491

Excoffier, L.; Laval, G. and Schneider, S. (2006) Arlequin ver 3.1 an integrated software package for population genetics data analysis (software) Bern: University of Berne Computational and molecular population genetics lab (CMPG), 2006 Available at: <http://cmpg.unibe.ch/software/arlequin3>. Last successful access in $27^{\text {nth }}$ Jan. 2007

Ferrão MAG, Fonseca AFA, Ferrão RG, Barbosa WM and Souza EMR (2009) Genetic divergence in conillon coffee revealed by RAPD markers. Crop Breed App Biotech, 9, 67-74

Ferdinandez YSN, Coulman BE (2002) Evaluating genetic variation and relationships among two bromegrass species and their hybrid using RAPD and AFLP markers. Euphytica, 125, 281-291 
Ferreira, C.F.; Alves, E.; Pestana, K.N.; Junghans, D.T.; Kobayashi, A.K.; Santos, V.J.; Silva, R.P.; Silva, P.H., Soares, E. and Fukuda, W. (2008) Molecular characterization of cassava yellow orange roots for beta carotene improvement. Crop Breed App Biotech, 8, 2329

Fowlie, J.A. (1977) The Brazilian bifoliate Cattleyas and their color varieties. Azul Quinta Press

Goh, S.H.; Kim, M.J.; Lee, J.S.; Ryu, K.H. (2006) Genetic diversity and phylogenetic relationships among and within species of oriental cymbidiums based on RAPD analysis. Sci Hortic, 108, 79-85

Holsinger, K.E., Wallace, L.E. (2004) A bayesian approach for the analysis of population genetic structure: an example from Platanthera leucophaea (Orchidaceae). Mol Ecol, 13, 887-894

Jimenez, J.F.; Sánchez-Gómez, P.; Guemes, J.; Werner, O. and Roselló JA (2002) Genetic variability in a narrow endemic snapdragon (Anthirrhinum subbaeticum, Scrophulariaceae) using RAP markers. Hered, 89, 387393

Koinange, E.M.K.; Singh, S.P. and Gepts, P. (1996) Genetic control of the domestication syndrome in common bean. Crop Sci, 36, 1037-1045

Lacerda, K.G., Miranda, F.E.L.F.; Machado, E.F.; Santos, C.P.; Endsfeldz, W.F.; Hirasawa, A.; Gloeden, H. and Kameyama M (1995) Brazilian Orchids. Sodo Publishing. pg. 301-305

Li, A. and Ge, S. (2006) Genetic variation and conservation of Changnienia amoena, an endangered orchid endemic to China. Plant Syst Evol, 258, 251-260

Lim, S.-H.; Teng, P. C.-P.; Lee, Y.-H. and Goh, C.-J. (1999) RAPD analysis of some species in the genus Vanda. Ann Bot, 83, 193-196

Menezes, C.C.E.; Sediyama, T.; McDonald, M.B. and Dias, E.D.C.F.S. (2002) Análise da pureza Genética e discriminação de cultvares de vinca (Catharanthus roseus (L.) G .Don) usando "Randon Amplified Polymorphic DNA" em DNA extraído de sementes e folhas. Rev Bras Sementes, 24, 279-285

Pires, J.C. and Sytsma, K.J. (2002) A phylogenetic evaluation of a biosystematic framework: Brodiaea and related petaloid monocots (Themidaceae). Amer J Bot 89, 1342-1359

Rohlf, F.J. (1998) NTSYS- Pc: numerical taxonomy and multivariate analysis system version 2.0 user's guide New York: Exeter Software. Disponível em: <http://www.exetersoftware.com/cat/ntsyspc/ntsysguide. pdf>. Acesso em: 10 março 2007.

Salamini, F.; Ozkan, H.; Brandolini, A.; Schäfer-Pregl, R and Martin, W. (2002) Genetics and geography of wild cereal domestication in the near east. Nature Reviews: Gen, 3, 429-441

Shaw, R.J.; Acharya, L. and Mukherjee, A.K. (2009) Assessment of genetic diversity in a highly valuable medicinal plant Catharanthus roseus using molecular markers. Crop Breed App Biotech, 9, 52-59.
Srivastava, R.; Shukla, S.; Soni, A. and Kumar, A. (2009) RAPD-based genetic relationships in different Bougainvillea cultivars. Crop Breed App Biotech, 9, 154-163

Torezan, J.M.D.; Souza, R.F.; Ruas, P.M.; Ruas, C.F.; Camargo, E.H.; Vanzela, A.L.L. (2005), Genetic variability of pre and post-fragmentation cohorts of Aspidosperma polyneuron Muell. Arg. (Apocynaceae). Braz Arch Biol ,Tech, 48, 171-180.

van den Berg, C. (2008), New combinations in Cattleya. Neodiversity, 3, 3-12

van den Berg, C.; Ryan, A.; Cribb, P.J.; Chase, M.W. (2002), Molecular phylogenetics of Cymbidium (Orchidaceae:Maxillarieae): sequence data from internal transcribed spacers (ITS) of nuclear ribosomal DNA and plastid matK. Lindleyana, 17, 102-111

Vieira, E.A.; Castro, C.M.; Oliveira, A.C.; Carvalho, F.I.F.; Zimmer, P.D.; Martins, L.F. (2004), Genetics structure of annual ryegrass (Lolium multiflorum) populations estimated by RAPD. Sci Agr, 61, 407-413

Walace, L.E. (2002), Examining the effects of fragmentation on genetic variation in Platanthera leucophaea (Orchidaceae): Inferences from allozyme and random amplified polymorphic DNA markers. Plant Species Biol, 17, 37-49

Wang, R.L.; Stec, A.; Hey, J.; Likens, L. and Doebley, J. (1999) The limits of selection during maize domestication. Nature, 398, 236-239

Weeden, N.F. (1992), Inheritance and reliability of RAPD markers. In: Symposium on applications of rapd technology to plant breeding, 1, 1992. Anais... Minneapolis: Crop Science Society of America/American Society for Horticultural Science/American Genetic Association. p.12-1.

Wildcatt Database CO. Wildcatt Orchids. Estados Unidos: WILDCATT DATABASE CO. 2002. Database of hybrid orchid registration.

Williams, J.G.K.; Kubelik, A.R.; Livak, K.J.; Rafalski, J.A. and Tingey, S.V. (1990), DNA polymorfisms amplified by arbitrary primers are useful as genetic markers. Nucleic Acids Res, 18, 6531-6535

Withner, C.L. (1988). The Cattleyas and their Relatives. Volume I The Cattleyas; Timber Press

Wright, S. (1978) Evolution and the genetics of populations. Vol 4. Variability within and among natural populations. University of Chicago Press, Chicago

Yanaka, Y.F.; Dall'Agnol, M.; Schifino-Wittmann, M.T.; Barreto Dias, P.M.; Gomes, K.E. (2005), Variabilidade genética em populações naturais de Bromus auleticus Trin. ex Nees (Poaceae) com base em isoenzimas e marcadores RAPD. Rev Bras Zootec, 34, 1897-1904

Received: April 06, 2010; Revised: September 14, 2010; Accepted: May 23, 2011. 